\title{
Comparative Efficacy of Amphotericin B Lipid Complex and Liposomal Amphotericin B for the Treatment of Invasive Fungal Infections in HSCT Recipients and other Immunocompromised Patient Populations with Hematologic Malignancies: A Critical Review
}

\author{
Jayesh Mehta ${ }^{*}, 1$, Julie Blake ${ }^{2}$ and Charles Craddock ${ }^{3}$ \\ ${ }^{I}$ The Robert H Lurie Comprehensive Cancer Center, Northwestern University, Chicago, USA \\ ${ }^{2}$ Strategen Ltd, $2 \& 3$ Stable Court, Herriard Park Estate, Herriard, Basingstoke, RG25 2PL, United Kingdom \\ ${ }^{3}$ Queen Elizabeth Hospital, Birmingham, B15 2TH, United Kingdom
}

\begin{abstract}
Amphotericin B is an important agent for the treatment of invasive fungal infections in immunocompromised patients because of its broad spectrum. However, its toxicities and the availability of alternative agents limit its application. Lipid-based formulations of amphotericin B, such as amphotericin B lipid complex (ABLC) and liposomal amphotericin B (L-AMB), are less nephrotoxic and as effective as conventional amphotericin B. However, because of their similarities, choosing between the two formulations remains a challenge. The majority of prospective and retrospective comparative studies have shown equivalence in terms of efficacy although some subset analyses favor ABLC over L-AMB. While both drugs penetrate well in the reticuloendothelial system, ABLC gets concentrated in the lungs to a much greater extent. This may have clinical implications because the lungs are the commonest site of invasive fungal infections. L-AMB is associated with less infusion-related adverse effects and less nephrotoxicity than ABLC. ABLC has been shown to be more cost-effective than L-AMB, although this is affected by variable institutional contracts and pricing. The choice between the two drugs should be based upon due consideration of all these factors.
\end{abstract}

Keywords: Amphotericin B lipid complex, fungal infections, immunocompromised patients.

\section{INTRODUCTION}

Invasive fungal infections are a significant cause of morbidity and mortality in severely immunocompromised patients including those with hematologic malignancies and recipients of solid-organ or hematopoietic stem cell transplantation (HSCT). Although Aspergillus and Candida species remain the most common pathogens, the spectrum of invasive mycoses is changing with emergence of other opportunistic fungal pathogens such as Fusarium, Zygomycetes and Scedosporium [1-4]. While all of these are potentially life-threatening, invasive pulmonary infections with mold (aspergillosis and zygomycosis) tend to be particularly serious $[5,6]$.

Amphotericin B has been the cornerstone of antifungal therapy since its discovery in 1956 due to its broad activity against a wide range of fungi including Aspergillus and Candida species. However, due to its lack of selective activity against fungal cell membranes, conventional amphotericin B (C-AMB) is toxic [7]; significantly limiting its therapeutic utility. The last $10-15$ years have seen the development of several new broad-spectrum antifungal agents, including lipid formulations of amphotericin B, broad spectrum triazoles (voriconazole and posaconazole),

*Address correspondence to this author at the Northwestern University Medical School, Hematology/ Oncology, 676 North St. Clair Street, Suite 850, Chicago, IL 60611-2927, USA; Tel: 001312695 6180; Fax: 001312 6956189 ; E-mail: j-mehta@northwestern.edu and the echinocandins (caspofungin, micafungin and anidulafungin). All of these agents are very effective against Aspergillus and Candida species, and have safety profiles that are superior to C-AMB. With the advent of these new agents, the use of amphotericin has declined considerably (Fig. 1). However, unlike the lipid formulations of amphotericin $\mathrm{B}$, the activity of the new agents against pathogenic zygomycetes is limited [8]. Indeed, there are questions about the activity of posaconazole - a drug thought to be active against zygomycetes [9] and a case of breakthrough zygomycosis has been reported in a patient receiving posaconazole [10]. Breakthrough infections have been reported with all of the novel agents [11-13].

The development of resistance and the increasing number of invasive mold infections has renewed interest in lipidbased formulations of amphotericin B as a potential therapeutic option in appropriate clinical situations. The decreased nephrotoxicity of these agents allows higher individual and cumulative doses of amphotericin to be given [14]. Amphotericin B lipid complex (ABLC; Abelcet ${ }^{\circledR}$, Cephalon) and liposomal amphotericin B (L-AMB; AmBisome ${ }^{\circledR}$, Gilead/Fujisawa), the two commonly used lipid-based formulations, are at least as effective as C-AMB in the treatment of invasive fungal infections, are less nephrotoxic and are associated with a lower risk of infusion-related reactions [15]. The biochemical, pharmacokinetic and pharmacodynamic characteristics of these preparations differ $[14,15]$, and there is considerable debate concerning their comparative clinical effectiveness, tolerability and cost. 


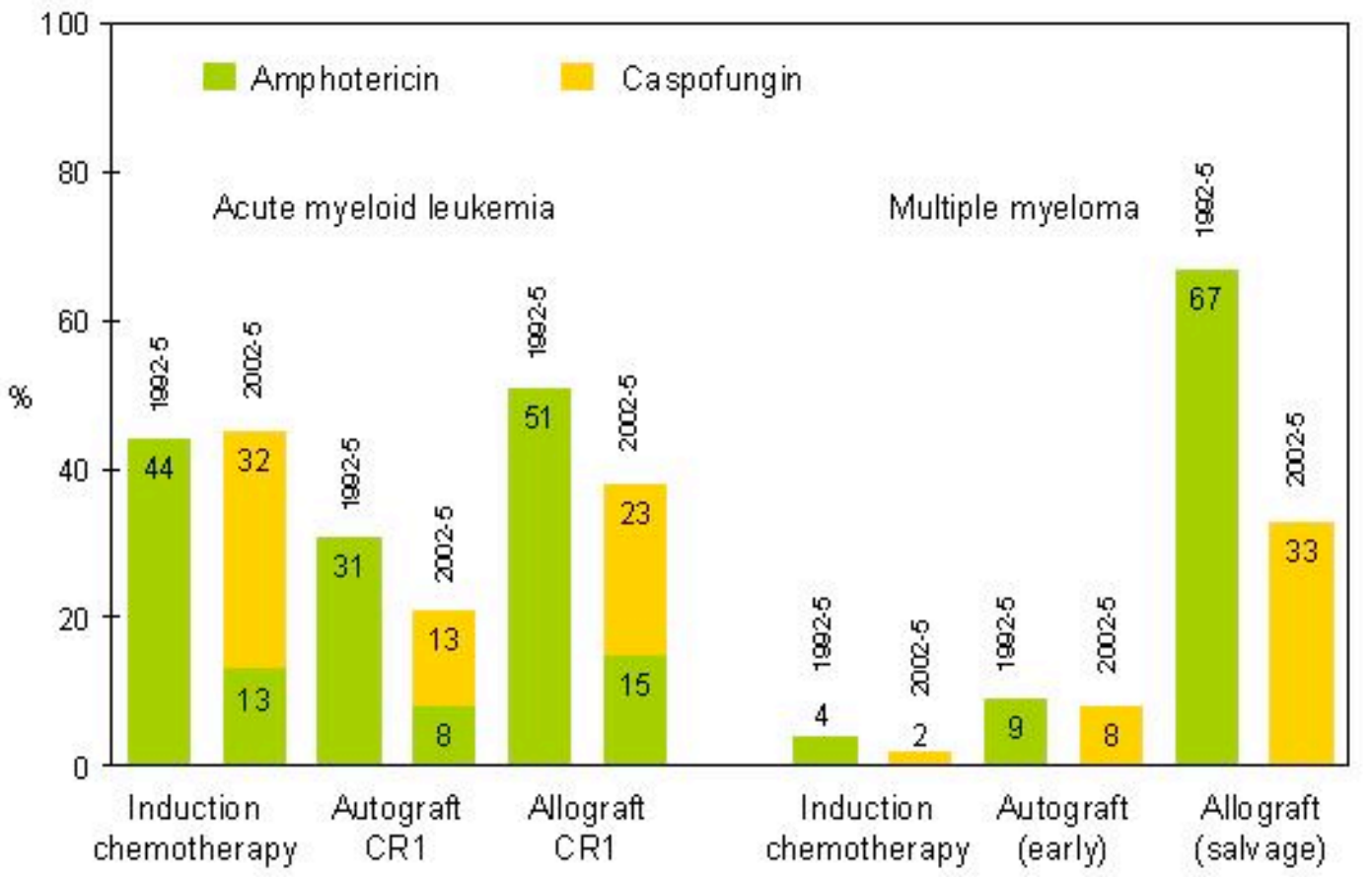

Fig. (1). Changing pattern of amphotericin use. The 1992-95 period represents use of amphotericin (mostly conventional amphotericin B) at the Royal Marsden Hospital, Surrey, UK. The 2002-05 period represents use of amphotericin (ABLC or L-AMB only) at the Northwestern Memorial Hospital, Chicago. The numbers represent the proportion of patients receiving amphotericin or an alternative antifungal agent in acute myeloid leukemia (AML) and multiple myeloma at various stages of therapy: during induction therapy or within the first 6 weeks of an autograft or an allograft. Amphotericin was the sole agent used in the earlier period, and caspofungin was the alternative in the later period. The use of amphotericin declined by $70 \%$ in AML and was eliminated in myeloma.

\section{COMPARATIVE EFFICACY OF LIPID-BASED AM- PHOTERICIN B FORMULATIONS AND CONVEN- TIONAL AMPHOTERICIN B}

A systematic review comparing lipid-based amphotericin $\mathrm{B}$ formulations to conventional amphotericin in the treatment of systemic fungal infections identified 7 randomized comparative studies [15]. The use of lipid-based formulations was found to reduce the all-cause mortality risk significantly compared to C-AMB - odds ratio (OR) 0.72 ; $95 \%$ confidence interval (CI) 0.54-0.97. Moreover, there was no significant difference in efficacy between the different lipidbased formulations and C-AMB (OR 1.21; 95\% CI: 0.981.49). The review, however, did not include comparative studies of ABLC and L-AMB.

The aim of this review is to examine the key published evidence on the comparative efficacy of ABLC and L-AMB in the treatment of invasive fungal infections in HSCT recipients and other immunocompromised patient populations with hematologic malignancies. Amphotericin B colloid dispersion has been shown to have a higher rate of infusionrelated adverse effects than C-AMB in two randomized, blinded studies [16, 17], and has not been dealt with in this review because of paucity of data and limited clinical use.

\section{COMPARATIVE EFFICACY OF ABLC AND L-AMB}

An initial search was undertaken in PubMed using the following search terms: "abelcet", "amphotericin B lipid complex", "amBisome", "liposomal amphotericin B" and "drug efficacy". The searches were restricted to clinical trials, meta-analyses, case reports, and comparative studies published in English, between 1966 and 2011. Other electronic databases and relevant websites were also searched: ClinicalTrials.gov, National Institute for Health and Clinical Excellence (NICE) and Cochrane Collaborations. All clinical studies and reports that compared the efficacy of ABLC and L-AMB in the treatment of invasive fungal infections in HSCT recipients and other immunocompromised patient populations with hematologic malignnancies were included. Citations were assessed for inclusion based on the study title and abstract. Papers investigating the use of aerosolised forms of ABLC or L-AMB were excluded, as were studies investigating prophylaxis for visceral leishmaniasis.

In total, 6 published studies were identified that compared the use of ABLC and L-AMB in the treatment of suspected or documented fungal infections or prolonged neutropenic fever (Table 1) [18-23], one of which was a randomized, double-blind study [19]. The majority of the patients treated in these studies had malignant diseases, were neutropenic and/or immunosuppressed, and a significant proportion were HSCT recipients.

The first study to be published was a small retrospective analysis by Clark et al. [18] comparing ABLC at a median daily dose of $4.8 \mathrm{mg} / \mathrm{kg}$ with L-AMB at a median daily dose of $1.9 \mathrm{mg} / \mathrm{kg}$ for the treatment of suspected or documented fungal infections in 58 adult patients with hematologic malignancies. Lipid-based formulations were used if there was progression of underlying proven or suspected fungal infection, or if there was renal or hepatic impairment. Over 
Table 1. Summary of Studies Comparing the Efficacy of ABLC and L-AMB

\begin{tabular}{|c|c|c|c|c|c|c|c|c|}
\hline \multirow{2}{*}{$\begin{array}{l}\text { Author } \\
\text { and } \\
\text { Year }\end{array}$} & \multirow{2}{*}{ Study Design } & \multirow{2}{*}{ Patients } & \multirow{2}{*}{ Treatment Groups } & \multicolumn{2}{|c|}{$\begin{array}{c}\text { Hematopoietic Stem Cell } \\
\text { Transplantation }\end{array}$} & \multicolumn{2}{|c|}{ Response Rate } & \multirow{2}{*}{$\mathbf{P}$} \\
\hline & & & & ABLC & L-AMB & ABLC & L-AMB & \\
\hline $\begin{array}{l}\text { Clark } \\
1998^{\mathrm{a}}\end{array}$ & Retrospective & $\begin{array}{l}\text { 59; hematologic } \\
\text { malignancies }\end{array}$ & $\begin{array}{l}\text { ABLC } 4.8 \mathrm{mg} / \mathrm{kg} / \mathrm{d} \\
\mathrm{L}-\mathrm{AMB} 1.9 \mathrm{mg} / \mathrm{kg} / \mathrm{d} \\
\text { (median doses) }\end{array}$ & $\begin{array}{l}\text { Allograft 39\% } \\
\text { Autograft 39\% }\end{array}$ & $\begin{array}{c}\text { Allograft } 63 \% \\
\text { Autograft } \\
28 \%\end{array}$ & $\begin{array}{c}\text { Overall } 78 \% \\
\text { Proven } 62 \% \\
\text { Suspected } 83 \%\end{array}$ & $\begin{array}{c}\text { Overall } 71 \% \\
\text { Proven } 42 \% \\
\text { Suspected } 79 \%\end{array}$ & $\begin{array}{l}\text { NS } \\
\text { NS } \\
\text { NS }\end{array}$ \\
\hline $\begin{array}{l}\text { Wingard } \\
2000^{\mathrm{b}}\end{array}$ & $\begin{array}{l}\text { Randomized, } \\
\text { double-blind }\end{array}$ & $\begin{array}{l}\text { 244; malignant } \\
\text { diseases with } \\
\text { neutropenic } \\
\text { fever }\end{array}$ & $\begin{array}{c}\text { ABLC } 5 \mathrm{mg} / \mathrm{kg} / \mathrm{d} \\
\mathrm{L}-\mathrm{AMB} 3 \mathrm{mg} / \mathrm{kg} / \mathrm{d} \\
\text { L-AMB } 5 \mathrm{mg} / \mathrm{kg} / \mathrm{d}\end{array}$ & $\begin{array}{l}\text { Allograft } 15 \% \\
\text { Autograft } 36 \%\end{array}$ & $\begin{array}{c}\text { Allograft } \\
15 \% / 16 \% \\
(3 / 5 \mathrm{mg} / \mathrm{kg}) \\
\text { Autograft } \\
31 \% / 33 \% \\
(3 / 5 \mathrm{mg} / \mathrm{kg})\end{array}$ & $\begin{array}{l}\text { Persistent fever: } \\
27 \%\end{array}$ & $\begin{array}{c}\text { Overall: } \\
3 \mathrm{mg} / \mathrm{kg} / \text { day: } 40 \% \\
5 \mathrm{mg} / \mathrm{kg} / \text { day: } 42 \% \\
\text { Persistent fever: } \\
3 \mathrm{mg} / \mathrm{kg} / \text { day: } 40 \% \\
5 \mathrm{mg} / \mathrm{kg} / \text { day: } 30 \%\end{array}$ & $\begin{array}{l}\text { NS } \\
\text { NS } \\
\text { NS } \\
\text { NS }\end{array}$ \\
\hline $\begin{array}{l}\text { Fleming } \\
2001^{\mathrm{c}}\end{array}$ & Prospective & 75; leukemia & $\begin{array}{l}\text { ABLC } 3 \mathrm{mg} / \mathrm{kg} / \mathrm{d} \\
\mathrm{L}-\mathrm{AMB} 4 \mathrm{mg} / \mathrm{kg} / \mathrm{d} \\
\text { (median doses) }\end{array}$ & Not reported & Not reported & $\begin{array}{c}\text { Overall 63\% } \\
\text { Proven } 30 \% \\
\text { Empiric } 94 \%\end{array}$ & $\begin{array}{l}\text { Overall 39\% } \\
\text { Proven } 29 \% \\
\text { Empiric } 62 \%\end{array}$ & $\begin{array}{c}0.03 \\
\mathrm{NS} \\
0.02\end{array}$ \\
\hline $\begin{array}{l}\text { Cannon } \\
2001^{\mathrm{d}}\end{array}$ & Observational & $\begin{array}{l}\text { 67; various, not } \\
\text { on dialysis }\end{array}$ & $\begin{array}{l}\text { ABLC } 5.3 \mathrm{mg} / \mathrm{kg} / \mathrm{d} \\
\mathrm{L}-\mathrm{AMB} 4.8 \mathrm{mg} / \mathrm{kg} / \mathrm{d} \\
\text { (mean doses) }\end{array}$ & $\begin{array}{c}22 \% \\
(2 \% \text { organ } \\
\text { transplants })\end{array}$ & $\begin{array}{c}29 \% \\
\text { (5\% organ } \\
\text { transplants) }\end{array}$ & Proven $87 \%$ & Proven $80 \%$ & NS \\
\hline $\begin{array}{l}\text { Mattiuzzi } \\
2004^{\mathrm{e}}\end{array}$ & $\begin{array}{l}\text { Prospective, } \\
\text { historic } \\
\text { control }\end{array}$ & $\begin{array}{l}\text { 131; AML and } \\
\text { MDS }\end{array}$ & $\begin{array}{c}\text { ABLC } 2.5 \mathrm{mg} / \mathrm{kg} \\
3 \mathrm{x} / \text { week } \\
\text { L-AMB } 3 \mathrm{mg} / \mathrm{kg} \\
3 \mathrm{x} / \text { week }\end{array}$ & Not reported & Not reported & $\begin{array}{l}79 \% \text { infection-free } \\
\text { at } 3 \text { weeks }\end{array}$ & $\begin{array}{c}67 \% \text { infection-free } \\
\text { at } 3 \text { weeks }\end{array}$ & 0.102 \\
\hline $\begin{array}{l}\text { Hachem } \\
2008^{\mathrm{f}}\end{array}$ & Retrospective & $\begin{array}{l}\text { 158; hematologic } \\
\text { malignancies }\end{array}$ & $\begin{array}{l}\text { ABLC 5-10 mg/kg/d } \\
\text { L-AMB 5-10 mg/kg/d }\end{array}$ & $\begin{array}{l}\text { Allograft } 37 \% \\
\text { Autograft } 6 \%\end{array}$ & $\begin{array}{l}\text { Allograft } 37 \% \\
\text { Autograft } 6 \%\end{array}$ & $12 \%$ & $12 \%$ & NS \\
\hline
\end{tabular}

$\mathrm{ABLC}=$ Amphotericin $\mathrm{B}$ lipid complex, $\mathrm{AML}=$ Acute myeloid leukemia, $\mathrm{L}-\mathrm{AMB}=$ Liposomal amphotericin $\mathrm{B}, \mathrm{MDS}=\mathrm{Myelodysplastic}$ syndrome.

${ }^{\mathrm{a}}[18]$

b $[19]$

c $[20]$

d $[21]$

$\mathrm{e}$
$\mathrm{f}$

$50 \%$ of patients in each group had received C-AMB previously. Overall response rates were comparable for both groups (ABLC: 78\% vs. L-AMB: 71\%). Response rates for evaluable patients with proven fungal infections were higher in the ABLC group compared with the L-AMB group $(62 \%$ vs. $42 \%$ ) but the difference was not statistically significant [18]. Other comparative studies have also shown no statistically significant difference in efficacy between the two formulations [19, 21]. Wingard et al. [19] assessed the comparative toxicity profiles of ABLC $5 \mathrm{mg} / \mathrm{kg} /$ day and LAMB 3 or $5 \mathrm{mg} / \mathrm{kg} /$ day in 244 neutropenic patients with fever persisting after 3 days of antibacterial therapy in a double-blind, randomized, multicenter study. Both treatment groups were comparable at baseline. About half the patients had undergone HSCT and the proportion of allograft recipients was comparable. The majority of patients had received prior antifungal therapy: $89 \%$ in the ABLC group and $81 \%$ in the L-AMB group. Although primarily designed to compare the safety profiles of the two lipid-based amphotericin B formulations, efficacy data were also collected to ensure that the reduced toxicity associated with these formulations did not compromise their efficacy. ABLC 5 $\mathrm{mg} / \mathrm{kg}$ was found to be equal to L-AMB $3 \mathrm{mg} / \mathrm{kg}$ in terms of the overall response rate $(33.3 \%$ vs. $40.0 \% ; \mathrm{P}=\mathrm{NS})$ and the treatment failure rate due to persistent fever ( $27 \%$ vs. $40 \%$; $\mathrm{P}=\mathrm{NS}$ ) [19].
These findings are consistent with those reported by Cannon et al. [21] who compared the efficacy of ABLC (mean daily dose $5 \mathrm{mg} / \mathrm{kg}$ ) with L-AMB (mean daily dose $4.8 \mathrm{mg} / \mathrm{kg}$ ) in 67 adults and children for the treatment of documented fungal infections or neutropenic fever. The majority of patients (70\% ABLC and 90\% L-AMB) had cancer. One patient in each treatment group had undergone solid organ transplant, and $22 \%$ of the ABLC recipients and $29 \%$ of the L-AMB recipients had undergone HSCT. Amongst patients with proven fungal infections, the response rate was $87 \%$ for ABLC and $80 \%$ for L-AMB. All 12 patients with documented Candida infections received ABLC and all responded (25\% complete and $75 \%$ partial). Amongst patients with non-Candida infections, $73 \%$ of ABLC recipients and $80 \%$ of L-AMB recipients responded. All patients in the ABLC group with febrile neutropenia responded; however, one patient in the L-AMB group with febrile neutropenia developed breakthrough pulmonary zygomycosis after 15 days of therapy.

In contrast, Fleming et al. [20] reported significantly higher overall response rates for patients treated with ABLC compared with those treated with L-AMB. In this prospective study of 75 adult leukemic patients with 82 episodes of suspected or proven fungal infections, patients were treated depending on their clinical situation: $3 \mathrm{mg} / \mathrm{kg}$ per day for fever of unknown origin (FUO), $4-5 \mathrm{mg} / \mathrm{kg}$ per day for 
sinusitis, cellulitis, and pneumonia with unknown pathogen, and $5 \mathrm{mg} / \mathrm{kg}$ per day for documented fungal infections. Baseline characteristics were similar between the two treatment groups, although a greater proportion of patients receiving $\mathrm{ABLC}$ was neutropenic at the start of therapy $(93 \%$ vs. $79 \% ; \mathrm{P}=0.07)$. The median total duration of therapy among responders was longer for L-AMB (13 vs. 8 days, respectively; $\mathrm{P}=0.08)$. The majority of patients with $\mathrm{FUO}$ and disseminated candidiasis were in the ABLC arm, whereas all patients with Fusarium infections received LAMB. The median daily dose of ABLC and L-AMB were 3 $\mathrm{mg} / \mathrm{kg}$ and $4 \mathrm{mg} / \mathrm{kg}$, range respectively. The mean duration of treatment for responders was 8 days for ABLC and 13 days for L-AMB. Using the intent-to-treat analysis, the overall clinical response rate was $63 \%$ vs. $39 \%$, respectively $(\mathrm{P}=0.03)$. Although the response rate for documented fungal infections was comparable for the two groups (ABLC 30\% vs. L-AMB 29\%), a higher response rate was seen amongst ABLC-treated patients compared with L-AMB-treated patients who received empiric treatment (94\% vs. 62\%; $\mathrm{P}=0.02)[20]$.

Limited data are available comparing the efficacy of ABLC and L-AMB as prophylactic agents in patients with acute myeloid leukemia (AML) or myelodysplastic syndrome, or in the treatment of invasive aspergillosis in patients with cancer. Mattuizzi et al. [22] reported that ABLC $2.5 \mathrm{mg} / \mathrm{kg} 3$ times per week and L-AMB $3 \mathrm{mg} / \mathrm{kg} 3$ times per week have similar efficacy in the prevention of fungal infections in newly diagnosed patients aged $\geq 15$ years with AML or high-risk myelodysplastic syndrome, with $49 \%$ of patients in each treatment group completing therapy without developing a suspected or documented fungal infection. Overall, mortality was similar between the two treatment groups. However, a higher proportion of ABLC recipients remained infection-free at 3 weeks (79\%vs. $67 \%$ with L-AMB), with a trend towards longer time-to-failure with $\mathrm{ABLC}(\mathrm{P}=0.102)$ [22]. In contrast, markedly lower response rates to those seen in previous comparative trials [18-21] were reported in a retrospective study undertaken by Hachem et al. [23] comparing the efficacy of ABLC and LAMB (5-10 mg/kg per day) used as either primary or salvage therapy in 381 patients with advanced hematologic malign- nancies and invasive aspergillosis. The overall response rate was approximately $8 \%$.

\section{DRUG DELIVERY TO SITES OF INFECTION}

ABLC and L-AMB differ substantially in the way amphotericin interacts with the lipid component. Thus, the structure and pharmacological profile of the two drugs is quite different (Table 2) [14,24]. ABLC is made up of relatively large lipid structures. The complexes have a mean particle diameter of 2-5 $\mu \mathrm{m}$ and appear as unique ribbon-like structures. L-AMB is a lyophilized formulation of amphotericin incorporated into small, rigid unilamellar liposomes, which are known to have long circulation times in the bloodstream [25].

Effective treatment of fungal infections requires adequate drug penetration and retention at the sites of infection. The large ribbon-like structure of ABLC is taken up rapidly by the mononuclear phagocytes of the reticuloendothelial system, and results in lower circulating amphotericin concentration and enhanced tissue penetration - especially the lungs (Table 3). Preclinical studies show that ABLC concentrates in the liver, spleen and lungs, and to a lesser degree, in the bone marrow [26,27]. After intravenous administration, most of the amphotericin B in L-AMB is retained in the liver and spleen and less in the lungs and kidney [25,28,29]. Amphotericin B concentration in lung tissue after ABLC administration exceeds that after L-AMB [14, 26-30].

Given the high mortality rate from pulmonary fungal infections, this affinity of ABLC for the lungs may have important clinical implications, particularly when choosing an appropriate therapy for treating fungal infections that primarily involve the lung. This was highlighted by Paterson et al. [31] who tested the susceptibilities of 12 strains of Aspergillus fumigatus and Aspergillus flavus from 11 patients who had failed treatment with C-AMB $(n=6)$ or LAMB $(\mathrm{n}=5)$. They reported that all the strains of Aspergillus fumigatus were susceptible to amphotericin (minimum inhibitory concentration: [MIC] $0.25-0.5 \mu \mathrm{g} / \mathrm{ml}$ ) as were 3 of the 6 Aspergillus flavus strains (MIC $1 \mu \mathrm{g} / \mathrm{ml}$ ), while 3 Aspergillus flavus strains were less susceptible (MIC 2

Table 2. Molecular Structure of ABLC and L-AMB

\begin{tabular}{|c|c|c|c|c|}
\hline Formulation & Liposome Category & Particle Size & Structure & Lipids (Molar Ratio) \\
\hline \hline ABLC & Multilamellar vesicle fraction & $2-5 \mu \mathrm{m}$ & Lipid ribbon & $\begin{array}{c}\text { Dimyristoyl phosphatidylcholine : Dimyristoyl phosphatidylglycerol } \\
(7: 3)\end{array}$ \\
\hline L-AMB & Small unilamellar vesicles & $80 \mathrm{~nm}$ & Liposome & $\begin{array}{c}\text { Hydrogenated soy phosphatidylcholine : Distearoyl } \\
\text { phosphatidylglycerol : Cholesterol (10:5:4) }\end{array}$ \\
\hline
\end{tabular}

$\mathrm{ABLC}=$ Amphotericin B lipid complex, L-AMB = Liposomal amphotericin B.

Table 3. Pharmacokinetic Characteristics of ABLC and L-AMB

\begin{tabular}{|c|c|c|c|c|}
\hline \multirow{2}{*}{ Formulation } & \multirow{2}{*}{ Plasma Peak Concentration Compared to C-AMB } & \multicolumn{3}{|c|}{ Tissue Amphotericin Concentrations Compared to C-AMB } \\
\hline & & Liver & Lung & Kidney \\
\hline ABLC & Lower & Higher & Higher & Similar \\
\hline L-AMB & Higher & Higher & Similar & Similar \\
\hline
\end{tabular}

$\mathrm{ABLC}=$ Amphotericin $\mathrm{B}$ lipid complex, $\mathrm{C}-\mathrm{AMB}=$ Conventional amphotericin $\mathrm{B} ; \mathrm{L}-\mathrm{AMB}=$ Liposomal amphotericin $\mathrm{B}$. 
$\mu \mathrm{g} / \mathrm{ml})$. They used high-performance liquid chromatography to measure amphotericin levels in post-mortem infected lung specimens, normal lung and normal liver from a patient with invasive aspergillosis who had received treatment for 28 days. The levels of amphotericin detected in infected lung were low $(0.1 \mu \mathrm{g} / \mathrm{g})$ while slightly higher levels were achieved in the surrounding normal lung $(0.67 \mu \mathrm{g} / \mathrm{g})$. They concluded that difficulty in treating invasive aspergillosis was likely due to poor tissue penetration of amphotericin rather than resistance to it.

On the other hand, Janoff et al. [32] reported that a heart transplant recipient who had received 3 doses of ABLC (5.3 $\mathrm{mg} / \mathrm{kg})$ had high tissue amphoterin concentrations $(\mathrm{mg} / \mathrm{g})$ at autopsy in the liver (196), spleen (290), and lungs (222), and low concentrations in the heart (5), lymph nodes (8), brain (2), and kidney (7).

Although differences have been observed between ABLC and L-AMB in terms of pulmonary concentrations of active drug and there may be a link between this and the trend towards greater efficacy of ABLC in some studies, the paucity of comparative data means that the conclusions that can be drawn are limited.

\section{COST CONSIDERATIONS}

The management of invasive fungal infections, particularly aspergillosis, the most significant fungal infection in immunocompromised patients, is associated with considerable healthcare costs [33]. In a pharmacoeconomic study of fungal infections, aspergillosis accounted for the largest incremental per person hospitalization costs followed by candidiasis [34]. In addition, transplant patients were found to have the highest mean additional hospitalization costs per person attributable to any type of fungal infection [34]. Given increasing healthcare costs and limited healthcare budgets, pharmacoeconomic analyses, which integrate clinical outcomes with data on costs and quality of life, are becoming increasingly important [35]. Therefore, in addition to efficacy and toxicity, cost-effectiveness is an important consideration when choosing an antimicrobial agent [36]. There are, however, a number of challenges with performing pharmacoeconomic studies in this patient population: a wide variety of invasive fungal infections, small patient populations in some clinical studies limiting the power and capacity to simplify results, and changing patterns of standards of care [37].

Several analyses have been undertaken to investigate the pharmacoeconomics of various antifungal drugs used in the management of invasive fungal infections [33, 35, 38-44], including C-AMB, ABLC and L-AMB in the treatment of invasive pulmonary aspergillosis [33]. A review of comparative studies suggests that $A B L C$ is a cost-effective option compared with C-AMB or other lipid-based formulations of amphotericin B [43]. However, there are limited pharmacoeconomic data on which of the two lipid-based formulations (ABLC or L-AMB) is more cost-effective. Based on the available evidence, a comparative pharmacoeconomic analysis published in 2004 suggested that ABLC was a more cost-effective option than L-AMB [44]. Calculations were based on acquisition costs of the antifungal agents, cost of concomitant therapy, and costs associated with the treatment of adverse events or treatment failure.

\section{TOLERABILITY}

Although higher rates of nephrotoxicity have been reported for ABLC in one of the 6 studies [19], nephrotoxicity is comparable in the other studies. The case study below illustrates the clinical course of a patient to show how serum creatinine levels fluctuate - and may explain the higher nephrotoxicity rates seen in the blinded study [19], where it was not specified whether nephrotoxicity reflected peak data or data from baseline to the last drug dose. ABLC is associated with a higher rate of infusion-related reactions, but these can be managed with regulation of the rate of administration and appropriate premedications [45-47]. ABLC and L-AMB are also less nephrotoxic than C-AMB.

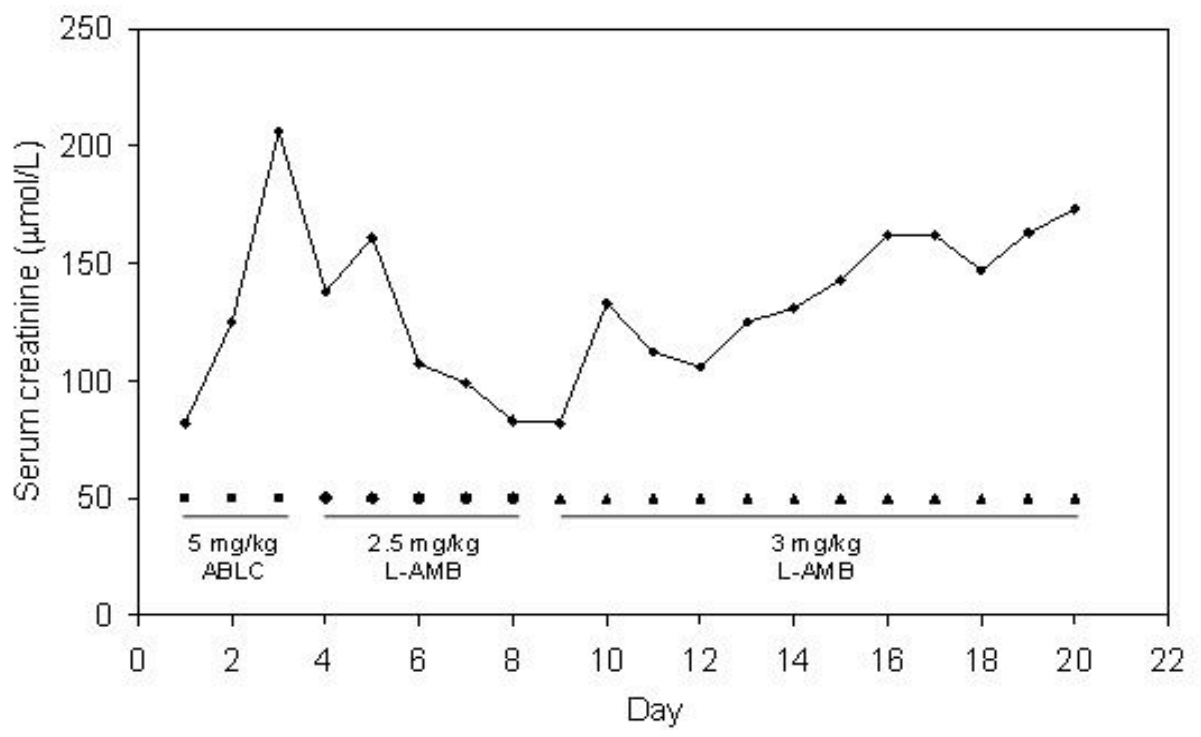

Fig. (2). Effect of ABLC and L-AMB on renal function in a myeloma patient with aspergillosis. Each day's serum creatinine level represents the level before drug administration. 


\section{Case Study}

A female patient with myeloma was given ABLC at an initial dose of $5 \mathrm{mg} / \mathrm{kg} /$ day for the treatment of pulmonary aspergillosis. Blood samples were taken prior to the administration of the antifungal agent and serum creatinine levels were measured daily. Serum creatinine levels increased from $82 \mu \mathrm{mol} / \mathrm{L}$ on Day 1 to $125 \mu \mathrm{mol} / \mathrm{L}$ on Day 2 (Fig. 2). By Day 3 the patient's serum creatinine levels had more than doubled $(206 \mu \mathrm{mol} / \mathrm{L})$. ABLC was discontinued and on Day 4, the patient was switched to L-AMB at an initial dose of $2.5 \mathrm{mg} / \mathrm{kg} / \mathrm{day}$. On Day 4, serum creatinine levels had fallen to $138 \mu \mathrm{mol} / \mathrm{L}$, which was actually a reflection of the effect of the first 3 days of ABLC therapy rather than the effect of L-AMB therapy, as the bloods were drawn before L-AMB was administered. This was further evidenced by the fact that once the dose of L-AMB was increased to $3 \mathrm{mg} / \mathrm{kg} /$ day, the patient's serum creatinine levels started to increase once again from $82 \mu \mathrm{mol} / \mathrm{L}$ on Day 8 to $133 \mu \mathrm{mol} / \mathrm{L}$ on Day 10 , peaking at $173 \mu \mathrm{mol} / \mathrm{L}$ by Day 20 . This case study suggests that a short-term increase in creatinine may be seen with these drugs, which settle down after a few days.

\section{CONCLUSIONS}

The major advantage of lipid-based formulations of amphotericin B is the reduction in the adverse effects associated with C-AMB. When the use of amphotericin is called for, the choice of the lipid amphotericin preparation used should be based on clinical efficacy and then cost. Selecting the most appropriate lipid-based formulation of amphotericin remains a challenge to many clinicians. While high-quality evidence from randomized, controlled trials is limited, and the sample size of the treatment groups in many of the published trials is relatively small, the data from these 6 studies in aggregate indicate that ABLC and L-AMB are effective in the treatment of suspected or documented fungal infections. The poor outcomes observed in the retrospective study in patients with hematologic malignancies and invasive aspergillosis may have been due to the fact that most of the selected patient population in the study either had advanced disease or were critically ill, and approximately one-third of the patients had undergone allogeneic HSCT within the prior year [23].

Although comparative studies have found no or limited significant differences in efficacy between ABLC and L$\mathrm{AMB}$, when taken together, there appears to be a trend towards higher overall response rates for ABLC. Furthermore, there are theoretical tissue distribution advantages in using ABLC. The advantage seen for ABLC over L-AMB in terms of efficacy in some of the studies should ideally be explored further in a randomized study. In terms of cost, ABLC is less expensive than L-AMB. These potential advantages of ABLC need to be balanced against the better tolerability of L-AMB.

\section{ABBREVIATIONS}

ABLC $=$ Amphotericin B lipid complex
L-AMB $=$ Liposomal amphotericin B
HSCT $=$ Hematopoietic stem cell transplantation

$\mathrm{C}-\mathrm{AMB}=$ Conventional amphotericin $\mathrm{B}$

$\mathrm{AML}=$ Acute myeloid leukemia

OR $=$ Odds ratio

CI $=$ Confidence interval

ANC $=$ Absolute neutrophil count

FUO $=$ Fever of unknown origin

MIC = Minimum inhibitory concentration

\section{ACKNOWLEDGEMENTS}

This review is based upon presentations by $\mathrm{JM}$ and $\mathrm{CC}$ at a scientific meeting on fungal infections organized by Strategen Ltd (UK) and sponsored by Cephalon Ltd (UK). $\mathrm{JM}$ and $\mathrm{CC}$ have received honoraria from Strategen Ltd (UK) in an advisory capacity. JB is an employee of Strategen. Editorial assistance for the review was provided by Strategen. Cephalon had no input into the content or development of the review. JM and CC are solely responsible for the selection of the scientific literature included, its interpretation, and the manuscript.

\section{REFERENCES}

[1] Singh N. Trends in the epidemiology of opportunistic fungal infections: predisposing factors and the impact of antimicrobial use practices. Clin Infect Dis 2001; 33: 1692-6.

[2] Maschmeyer G. The changing epidemiology of invasive fungal infections: new threats. Int J Antimicrob Agents 2006; 27S:S3-6.

[3] Pagona L, Caira M, Candoni A, et al. The epidemiology of fungal infections in patients with hematologic malignancies: the SEIFEM2004 study. Hematologica 2006; 91: 1068-75.

[4] Richardson M, Lass-Flörl C. Changing epidemiology of systemic fungal infections. Clin Microbiol Infect 2008; 14(Suppl 4): 5-24.

[5] Danner BC, Didilis V, Dörge H, Mikroulis D, Bougioukas G, Schöndube FA. Surgical treatment of pulmonary aspergillosis/mycosis in immunocompromised patients. Interact Cardiovasc Thorac Surg 2008; 7: 771-6.

[6] Morgan J, Wannemuehler KA, Marr KA, et al. Incidence of invasive aspergillosis following hematopoietic stem cell and solid organ transplantation: interim results of a prospective multicenter surveillance program. Med Mycol 2005; 43(Suppl 1): S49-58.

[7] Jamieson C. Fungal infections - pharmacological therapy. Hospital Pharmacist 2006; 13: 321-5.

[8] Walsh TJ, Kontoyiannis DP. What is the role of combination therapy in management of zygomycosis? Clin Infect Dis 2008; 47: 372-4.

[9] Ibrahim AS, Gebremariam T, Schwartz JA, Edwards JE, Spellberg B. Posaconazole mono- or combination therapy for treatment of murine zygomycosis. Antimicrobial Agents Chemother 2009; 53: $772-5$.

[10] Schlemmer F, Lagrange-Xelot M, Lacroix C, La Tour R, Socie G, Molina J-M. Breakthrough Rhizopus infection on posaconazole prophylaxis following allogenic stem cell transplantation. Bone Marrow Transplant 2008; 42: 551-2.

[11] Trifilio S, Singhal S, Williams S, et al. Breakthrough fungal infections after allogeneic hematopoietic stem cell transplantation in patients on prophylactic voriconazole. Bone Marrow Transplant 2007; 40: 451-6.

[12] Trifilio SM, Bennett CL, Yarnold PR, et al. Breakthrough zygomycosis after voriconazole administration among patients with hematologic malignancies who receive hematopoietic stem-cell transplants or intensive chemotherapy. Bone Marrow Transplant 2007; 39: 425-9.

[13] Madureira A, Bergeron A, Lacroix C, et al. Breakthrough invasive aspergillosis in allogeneic haematopoietic stem cell transplant recipients treated with caspofungin. Int J Antimicrob Agents 2007; 30: $551-4$. 
[14] Mehta J. Do variations in molecular structure affect the clinical efficacy and safety of lipid-based amphotericin B preparations? Leuk Res 1997; 21: 183-8.

[15] Barrett JP, Vardulaki KA, Conlon C, et al. A systematic review of the antifungal effectiveness and tolerability of amphotericin B formulations. Clin Ther 2003; 25: 1295-320.

[16] White MH, Bowden RA, Sandler ES, et al. Randomized, doubleblind clinical trial of amphotericin B colloidal dispersion vs. amphotericin B in the empirical treatment of fever and neutropenia. Clin Infect Dis 1998; 27: 296-302.

[17] Bowden R, Chandrasekar P, White MH, et al. A double-blind, randomized, controlled trial of amphotericin $\mathrm{B}$ colloidal dispersion versus amphotericin $\mathrm{B}$ for treatment of invasive aspergillosis in immunocompromised patients. Clin Infect Dis 2002; 35: 359-66.

[18] Clark AD, McKendrick S, Tansey PJ, Franklin IM, Chopra R. A comparative analysis of lipid-complexed and liposomal amphotericin B preparations in haematological oncology. $\mathrm{Br} \mathrm{J}$ Haematol 1998; 103: 198-204.

[19] Wingard JR, White MH, Anaissie E, Raffalli J, Goodman J, Arrieta A. A randomized, double-blind comparative trial evaluating the safety of liposomal amphotericin B versus amphotericin B lipid complex in the empirical treatment of febrile neutropenia. Clin Infect Dis 2000; 31: 1155-63.

[20] Fleming RV, Kantarjian HM, Husni R, et al. Comparison of amphotericin B lipid complex (ABLC) vs. AmBisome in the treatment of suspected or documented fungal infections in patients with leukemia. Leuk Lymphoma 2001; 40: 511-20.

[21] Cannon JP, Garey KW, Danziger LH. A prospective and retrospective analysis of the nephrotoxicity and efficacy of lipidbased amphotericin B formulations. Pharmacotherapy 2001; 21: 1107-14.

[22] Mattiuzzi GN, Kantarjian H, Faderl S, et al. Amphotericin B lipid complex as prophylaxis of invasive fungal infections in patients with acute myelogenous leukemia and myelodysplastic syndrome undergoing induction chemotherapy. Cancer 2004; 100: 581-9.

[23] Hachem RY, Boktour MR, Hanna HA, et al. Amphotericin B lipid complex versus liposomal amphotericin B monotherapy for invasive aspergillosis in patients with hematologic malignancy. Cancer 2008; 112: 1282-7.

[24] Torrado JJ, Espada R, Ballesteros MP, Torrado-Santiago S. Amphotericin B formulations and drug targeting. J Pharm Sci 2008; 97: 2405-25.

[25] Smith PJ, Olson JA, Constable D, Schwartz J, Proffitt RT, AdlerMoore JP. Effects of dosing regimen on accumulation, retention and prophylactic efficacy of liposomal amphotericin B. J Antimicrob Chemother 2007; 59: 941-51.

[26] Clark JM, Whitney RR, Olsen SJ, et al. Amphotericin B lipid complex therapy of experimental fungal infections in mice. Antimicrob Agents Chemother 1991; 35: 615-21.

[27] Olsen SJ, Swerdel MR, Blue B, Clark JM, Bonner DP. Tissue distribution of amphotericin B lipid complex in laboratory animals. J Pharm Pharmacol 1991; 43: 831-5.

[28] Andes D, Safdar N, Marchillo K, Conklin R. Pharmacokineticpharmacodynamic comparison of amphotericin B (AMB) and two lipid-associated AMB preparations, liposomal AMB and AMB lipid complex, in murine candidiasis models. Antimicrob Agents Chemother 2006; 50: 674-84.

[29] Olson JA, Adler-Moore JP, Schwartz J, Jensen GM, Proffitt RT. Comparative efficacies, toxicities, and tissue concentrations of amphotericin B lipid formulations in a murine pulmonary aspergillosis model. Antimicrob Agents Chemother 2006; 50: 2122-31.
[30] Matot I, Pizov R. Pulmonary extraction and accumulation of lipid formulations of amphotericin B. Crit Care Med 2000; 28: 2528-32.

[31] Paterson P, Seaton S, Prentice HG, Kibbler CC. Treatment failure in invasive aspergillosis: susceptibility of deep tissue isolates following treatment with amphotericin B. J Antimicrob Chemother 2003; 52: 873-6.

[32] Janoff AS, Perkins WR, Saletan SL, Swenson CE. Amphotericin B lipid complex (ABLCTM): a molecular rationale for the attenuation of amphotericin B related toxicities. J Liposome Res 1993; 3: 45171.

[33] Cagatay AA, Cosan F, Karadeniz A, et al. The clinical and pharmacoeconomic analysis of invasive aspergillosis in adult patients with haematological diseases. Mycoses 2008; 51: 328-35.

[34] Wilson LS, Reyes CM, Stolpman M, Speckman J, Allen K, Beney $\mathrm{J}$. The direct cost and incidence of systemic fungal infections. Value Health 2002; 5: 26-34.

[35] Bruynesteyn K, Gant V, McKenzie C, et al. A cost-effectiveness analysis of caspofungin vs. liposomal amphotericin B for treatment of suspected fungal infections in the UK. Eur J Haematol 2007; 78: 532-9.

[36] Rapp RP. Changing strategies for the management of invasive fungal infections. Pharmacotherapy 2004; 24: 4S-28S.

[37] Johnson MD, Kleinberg M, Danziger L, Ostrosky-Zeichner L. Pharmacoeconomics of antifungal pharmacotherapy - challenges and future directions. Expert Opin Pharmacother 2005; 6: 2617-32.

[38] Collins CD, Stuntebeck ER, DePestel DD, Stevenson JG. Pharmacoeconomic analysis of liposomal amphotericin B versus voriconazole for empirical treatment of febrile neutropenia. Clin Drug Investig 2007; 27: 233-41.

[39] Wingard JR, Wood CA, Sullivan E, Berger ML, Gerth WC, Mansley EC. Caspofungin versus amphotericin B for candidemia: a pharmacoeconomic analysis. Clin Ther 2005; 27: 960-9.

[40] Wingard JR, Leather HL, Wood CA, et al. Pharmacoeconomic analysis of caspofungin versus liposomal amphotericin B as empirical antifungal therapy for neutropenic fever. Am J Health Syst Pharm 2007; 64: 637-43.

[41] Cagnoni PJ, Walsh TJ, Prendergast MM, et al. Pharmacoeconomic analysis of liposomal amphotericin B versus conventional amphotericin B in the empirical treatment of persistently febrile neutropenic patients. J Clin Oncol 2000; 18: 2476-83.

[42] Lewis JS, Boucher HW, Lubowski TJ, Ambegaonkar AJ, Day DL, Patterson TF. Cost advantage of voriconazole over amphotericin B deoxycholate for primary treatment of invasive aspergillosis. Pharmacotherapy 2005; 25: 839-46.

[43] Martino R. Efficacy, safety and cost-effectiveness of Amphotericin B Lipid Complex (ABLC): a review of the literature. Curr Med Res Opin 2004; 20: 485-504.

[44] Kuti JL, Kotapati S, Williams P, Capitano B, Nightingale C, Nicolau D. Pharmacoeconomic analysis of amphotericin B lipid complex versus liposomal amphotericin B in the treatment of fungal infections. Pharmacoeconomics 2004; 22: 301-10.

[45] O'Connor N, Borley A. Prospective audit of the effectiveness of hydrocortisone premedication on drug delivery reactions following amphotericin B lipid complex. Curr Med Res Opin 2009; 25: 74954.

[46] Clevenbergh P, Jacobs F, Kentos A. Compassionate use of amphotericin B lipid complex (Abelcet) in life-threatening fungal infections: report of 30 courses. Clin Microbiol Infect 1998; 4: 1928.

[47] Craddock C, Anson J, Chu P, et al. Best practice guidelines for the management of adverse events associated with amphotericin B lipid complex. Expert Opin Drug Saf 2009; 9: 139-47.

(C) Mehta et al.; Licensee Bentham Open.

This is an open access article licensed under the terms of the Creative Commons Attribution Non-Commercial License (http://creativecommons.org/ licenses/by-nc/3.0/), which permits unrestricted, non-commercial use, distribution and reproduction in any medium, provided the work is properly cited. 